\title{
OPEN Validation of reference genes for quantitative PCR in the forest pest, Ips calligraphus
}

\author{
Mary Wallace \& Lynne K. Rieske
}

The six-spined ips, Ips calligraphus, is a North American bark beetle that can exploit most eastern North American Pinus species and can cause mortality. Biotic and abiotic disturbances weaken trees, creating breeding substrate that promotes rapid population growth. Management historically relied on silvicultural practices, but as forests become increasingly stressed, innovative management is needed. Manipulation of the cellular RNA interference (RNAi) pathway to induce gene silencing is an emerging means of insect suppression, and is effective for some bark beetles. Quantitative PCR (qPCR) is a powerful tool for analysis of gene expression, and is essential for examining RNAi. To compare gene expression among individuals, stably expressed reference genes must be validated for qPCR. We evaluated six candidate reference genes $(18 s, 16 s, 28 s$, ef1a, cad, coi) for stability under biotic (beetle sex, developmental stage, and host plant), and abiotic (temperature, photoperiod, and dsRNA exposure) conditions. We used the comprehensive RefFinder tool to compare stability rankings across four algorithms. These algorithms identified $18 \mathrm{~s}, 16 \mathrm{~s}$, and $28 \mathrm{~s}$ as the most stably expressed. Overall, $16 s$ and $28 s$ were selected as reference genes due to their stability and moderate expression levels, and can be used for $I$. calligraphus gene expression studies using $\mathrm{PPCR}$, including those evaluating RNAi.

Ips calligraphus, the six-spined ips, is a native North American bark beetle that can infest most Pinus species, including economically important species such as loblolly ( $P$. taeda), shortleaf ( . echinata), and slash ( $P$. elliottii $)^{1-3}$. Historically, I. calligraphus has been considered a secondary pest, utilizing volatile compounds produced by stressed trees to preferentially locate and infest those already in poor condition, then using sex pheromones to further attract conspecifics to suitable hosts ${ }^{4}$. Adults mate, and females then excavate oviposition galleries (Fig. 1), where eggs are laid and larvae develop, feeding within the phloem ${ }^{3}$. In the southeast region of the United States development requires 15-40 days (mean 25 days), allowing for multiple generations per year ${ }^{2}$. Typically, I. calligraphus infested trees are spread sporadically throughout the forest, and no management is necessary ${ }^{5}$. However, the increasing frequency and intensity of regional abiotic extremes ${ }^{6-8}$ has generated disturbed sites with an abundance of suitable breeding material, creating the potential for rapid population growth ${ }^{9,10}$. These post-disturbance population increases have elevated I. calligraphus beyond its status as a secondary pest to one responsible for significant economic losses ${ }^{5,11,12}$. Furthermore, I. calligraphus has historically been invasive in the Philippines and Jamaica ${ }^{5,13}$, and has more recently established populations in south mainland China ${ }^{14}$, well outside of its native range, and is classified as a Scolytinae at high risk of becoming invasive in the southern hemisphere ${ }^{15}$. This invasiveness, coupled with human-mediated disturbances and rapidly changing climatic conditions, has increased the risk that I. calligraphus poses to forest ecosystems, necessitating development of innovative, sustainable, and affordable management tools.

Management techniques relying on the knowledge and manipulation of genetic information have recently been deployed against agricultural pests ${ }^{16,17}$, but are only just emerging as a potential means of reducing forest pest populations ${ }^{18-21}$. Manipulating the RNA interference (RNAi) pathway serves as one example of this technology, exploiting the insect's own viral defense mechanism ${ }^{22}$ to target critical mRNAs, thus generating mortality in the target insect while showing extreme specificity, minimizing concerns of non-target effects ${ }^{21,23,24}$. RNAi functions through the introduction of species-specific double-stranded RNA (dsRNA), which is recognized by the endogenous RNAi pathway present in the target insect. The dsRNA is then cleaved by the enzyme dicer into 21-23 base pair strands known as small-interfering RNA (siRNA), which are incorporated into the RNAiinduced silencing complex (RISC) ${ }^{25}$. The siRNA is then used as a template for the RISC complex to bind to and cleave complementary mRNA using an Argonaute enzyme, preventing translation into protein ${ }^{25}$. If the targeted genes are essential, this process can cause insect mortality. Considering there must be a precise $\geq 16$ base pair 


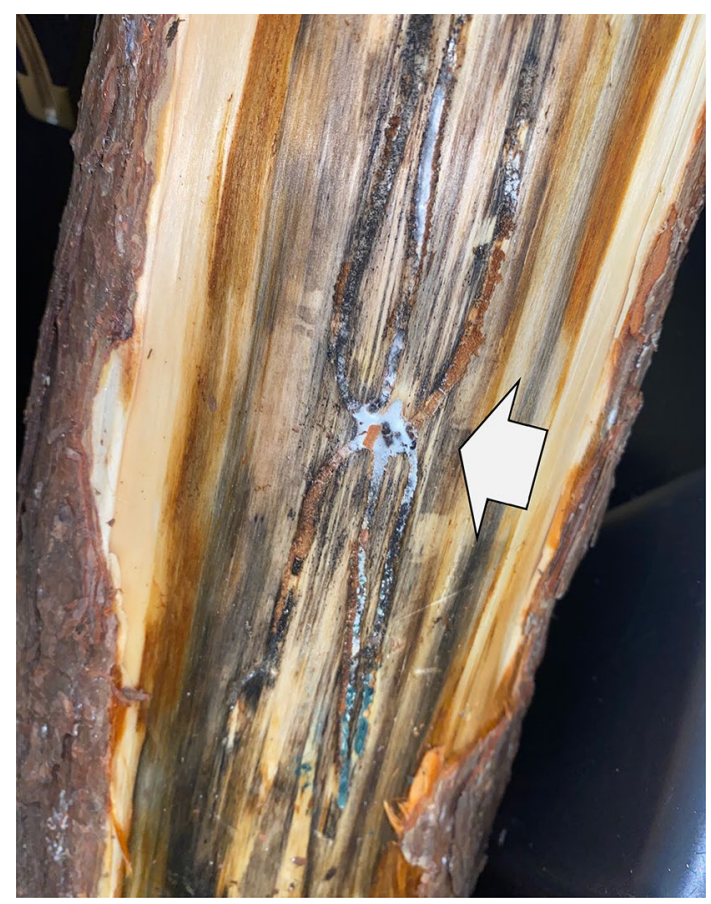

Figure 1. I. calligraphus gallery in a debarked P. taeda log showing an adult beetle with fungal growth, and blue staining associated with Ophiostoma spp.

match, or $>26$ base pair near-perfect match for the degradation to occur ${ }^{24}$, RNAi can be highly specific to both the species and transcripts being targeted, minimizing the risk of non-target effects, an important consideration for deployment. Given the susceptibility of other scolytines to RNAi, including the southern and mountain pine beetles, Dendroctonus frontalis ${ }^{19}$ and $D$. ponderosae ${ }^{20}$, the potential for developing and utilizing RNAi as a tool for I. calligraphus management is promising.

An established method of demonstrating gene silencing through the introduction of exogenous dsRNA involves evaluation of relative gene expression via quantitative PCR (qPCR). This requires selection of stably expressed endogenous controls, or reference genes, that can be used to interpret gene expression levels across samples that may have different mRNA levels due to methodological variation, rather than biological causes ${ }^{26,27}$. Commonly selected reference genes are those that are critical to cellular function, as these genes are most often stably expressed across cell types and environmental conditions. Reference genes must be validated across conditions relevant to a given experimental design before use as an endogenous control for qPCR in gene expression studies. The stability of a candidate reference gene can be quantitatively evaluated via algorithms such as GeNorm, NormFinder, delta-Ct, and BestKeeper, allowing for selection of the most reliable endogenous controls.

The goal of the present study is to identify stably expressed reference genes for use in relative gene expression analysis in I. calligraphus, including those valid for studies of exogenous dsRNA induced gene silencing. We evaluated six candidate housekeeping genes for stability across several biotic (beetle sex, developmental stage, and host plant) and abiotic (temperature, photoperiod, dsRNA exposure) conditions. This is the first validation of reference genes for I. calligraphus, and is a necessary step for future qPCR gene expression analyses. qPCR is essential for demonstrating gene knockdown from dsRNA exposure, which is the next step in working toward developing an RNAi-based pest suppression strategy for I. calligraphus.

\section{Results}

Across all treatments combined (Fig. 2) the most highly expressed gene is 18 s ribosomal RNA (18s) with Cq values ranging from 12.7 to 15.6 , while Ca2 carbamoyl-phosphate synthetase 2 (cad) has the lowest expression with Cq values ranging from 28.8 to 34.9 .

Cytochrome oxidase I (coi), has the greatest range of expression, with Cq values ranging from 23.9 to 35.1 . Of the remaining genes evaluated, 16s ribosomal RNA (16s), 28s ribosomal RNA (28s), and elongation factor 1-alpha (ef1a), are moderately expressed, with average Cq values ranging from 19.2 to 24.7.

The average $\mathrm{Cq}$ value of each candidate reference gene was determined for each condition, including beetle sex, developmental stage, host plant, temperature, light conditions, and dsRNA exposure (Fig. 3a-f). The relative level of expression for each candidate gene was consistent across all conditions, with $18 \mathrm{~s}$ having the highest expression, and cad being the least expressed. Across all conditions tested, coi was the most variable, having the largest range of $\mathrm{Cq}$ values.

GeNorm $^{28}$ uses a gene expression stability value (M) to determine stability; $M<1.5$ is required for a gene to be considered stable. All candidate genes tested had an $\mathrm{M}$ value below 1.5, with $16 \mathrm{~s}$ and $18 \mathrm{~s}$ being ranked equally as most stable (Fig. 4). NormFinder ${ }^{28}$ ranks candidate genes based on an overall stability value (SV); SV $>1$ indicates 


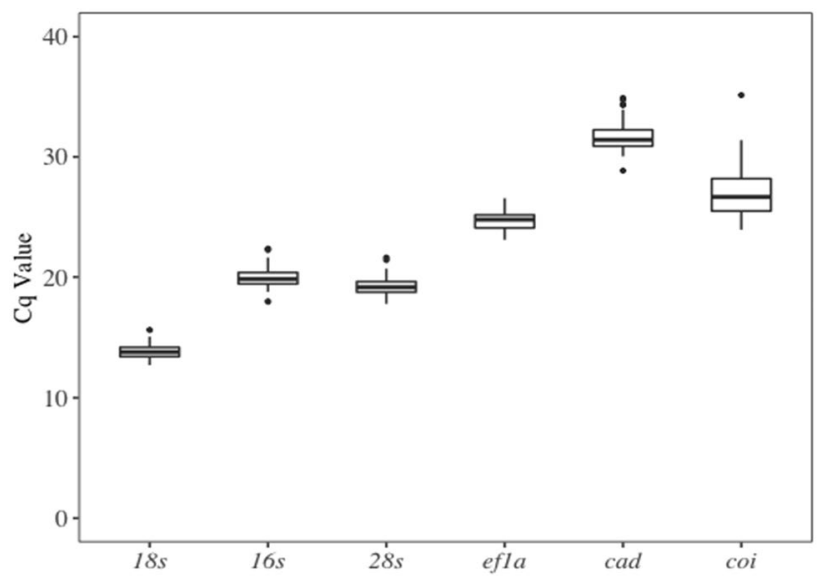

Figure 2. Cq values for each candidate reference gene across all treatments. Boxes encompass the 25th to 75 th percentiles, and whiskers represent 1.5 times the interquartile range. Outliers are indicated by dots.

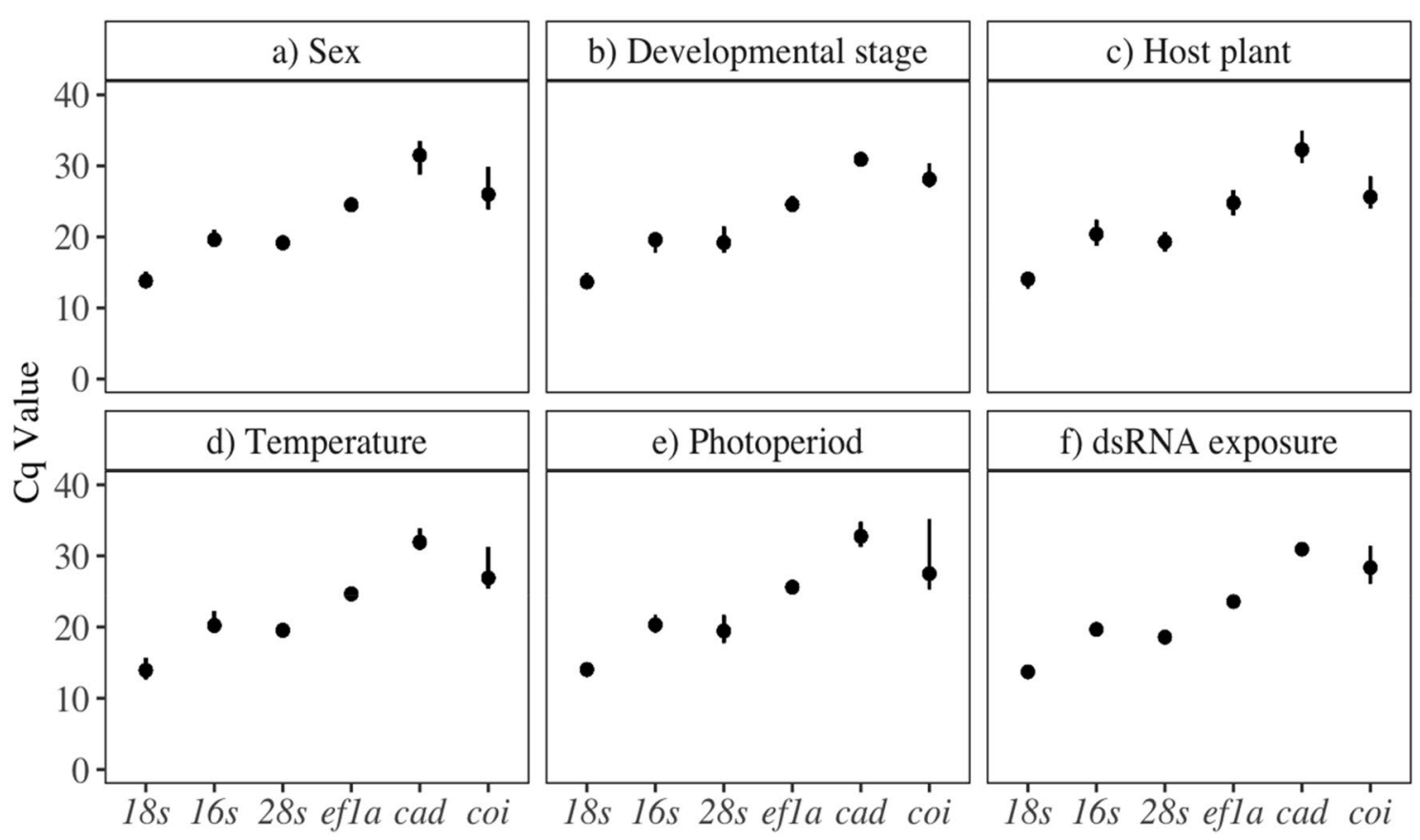

Figure 3. Average Cq values for each candidate reference gene by: (a) beetle sex, (b) developmental stage, (c) host plant, (d) temperature, (e) photoperiod, and (f) dsRNA exposure. Error bars represent the maximum and minimum Cq values, $\mathrm{n}=5$ beetles per treatment.

lower stability. $18 \mathrm{~s}$ and $16 \mathrm{~s}$ had the lowest SV scores, with $28 \mathrm{~s}$ and ef1a being the only other candidate genes to meet the threshold. BestKeeper ${ }^{28}$ uses standard deviation (SD) to determine stability, with a SD $<1$ more stable. Using this approach, all candidate genes except coi met the threshold for stable expression, but $18 \mathrm{~s}, 28 \mathrm{~s}$, and $16 \mathrm{~s}$ were ranked as the most stable. The comparative delta-Ct method also uses SD to determine stability, with a lower value indicating a more stable expression. Using the delta-Ct method, $18 s$ and $16 s$ were the most stable.

The geomean value was determined using the web tool RefFinder ${ }^{28}$, which gave a comprehensive ranking across the four algorithms, with $18 s$ ranking first, $16 s$ ranking second, and $28 s$ ranking third. The four top-ranking reference gene candidates met the stability parameters of each of the algorithms (Table 1). Of these, $16 \mathrm{~s}$ and $28 \mathrm{~s}$ were selected as reference genes, as they have similar levels of stability to $18 \mathrm{~s}$ across the algorithms used, while having a more moderate $\mathrm{Cq}$ values, allowing them to be more applicable to evaluating genes with moderate levels of expression. 


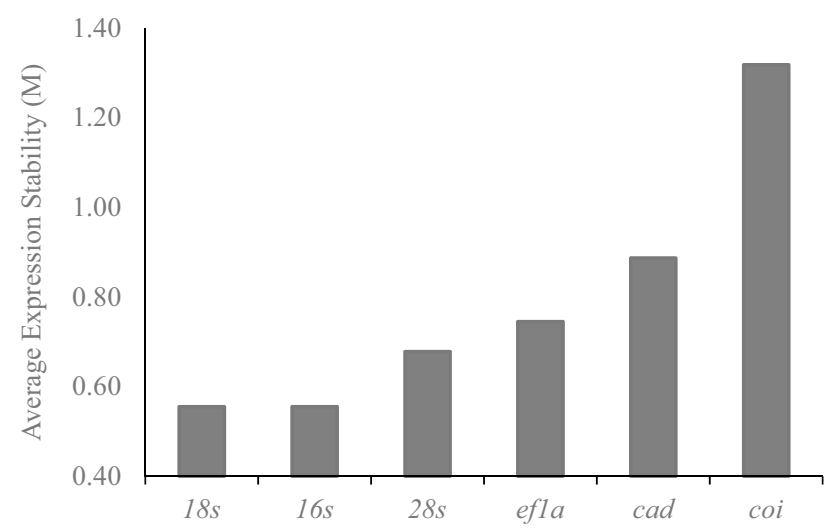

Figure 4. Average expression stability values $(\mathrm{M})$ of the 6 candidate reference genes plotted from most stable (left) to least stable (right) analyzed by the GeNorm software.

\begin{tabular}{|l|l|l|l|l|l|l|l|l|l|l|l|}
\hline \multirow{2}{*}{ Gene } & \multicolumn{3}{l}{ GeNorm } & \multicolumn{2}{l}{ NormFinder } & \multicolumn{2}{l|}{ BestKeeper } & \multicolumn{2}{l|}{ delta-Ct } & \multicolumn{2}{l|}{ Comprehensive } \\
\cline { 2 - 13 } & M & R & SV & R & SD & R & SD & R & GM & R \\
\hline $18 s$ & 0.56 & 1 & 0.17 & 1 & 0.50 & 1 & 1.01 & 1 & 1.00 & 1 \\
\hline $16 s$ & 0.56 & 1 & 0.46 & 2 & 0.64 & 3 & 1.08 & 2 & 1.86 & 2 \\
\hline $28 s$ & 0.68 & 2 & 0.73 & 4 & 0.59 & 2 & 1.18 & 4 & 3.13 & 3 \\
\hline ef1a & 0.75 & 3 & 0.52 & 3 & 0.65 & 4 & 1.10 & 3 & 3.46 & 4 \\
\hline$c a d$ & 0.89 & 4 & 1.02 & 5 & 0.91 & 5 & 1.36 & 5 & 5.00 & 5 \\
\hline coi & 1.32 & 5 & 2.09 & 6 & 1.64 & 6 & 2.18 & 6 & 6.00 & 6 \\
\hline
\end{tabular}

Table 1. Stability rankings of the 6 candidate reference genes using RefFinder: GeNorm, NormFinder, BestKeeper, delta-CT, and a comprehensive rank from RefFinder. R: ranking; M: gene expression stability; SV: stability value; SD: standard deviation; GM: geomean value.

\section{Discussion}

qPCR is an indispensable tool for evaluating gene expression, an important aspect of many genetic studies, and essential for demonstrating RNAi-induced gene silencing, as its sensitivity permits detection of even minor differences between samples ${ }^{27,29,30}$. However, this sensitivity can also be a limitation, as any differences in baseline transcription levels, variation in sample preparation, or technical inconsistencies become evident. To normalize gene expression between samples for qPCR quantification of mRNA levels, internal controls that are stably expressed in various experimental conditions are needed ${ }^{26}$. The selection and use of stable reference genes allow researchers to normalize variation between samples, thus giving a more accurate representation of gene expression differences and avoiding error.

Despite some variation in ranking, the top four reference genes $(18 s, 16 s, 28 s$, and ef1a) were consistently stable regardless of the algorithm used. In addition, they were consistently stable across the biotic and abiotic conditions we tested, and these conditions may vary across different experimental designs, increasing the versatility of our selected reference genes for use in gene expression studies. The conserved nature of these essential genes should also allow for their use in genetically variable individuals, though further investigation is required to confirm this among different populations or subspecies. Stability in dsRNA-exposed beetles and individuals of different developmental stages could allow for these same reference genes to be used for normalizing gene expression in RNAi experiments using oral delivery of dsRNA in a sucrose solution, with treatment at multiple life stages, an important factor given that I. calligraphus causes damage both through larval feeding, and during dispersal as adults by carrying damaging microorganisms to naïve hosts. Additionally, RNAi manipulations allow for investigations into gene function using reverse genetics, serving as a technique that can illuminate the effects of reduced gene expression at a variety of life stages, including genes for which knockouts prevent complete development.

This study provides an essential foundation for future gene expression work in the experimental conditions analyzed. Additionally, the selection of reference genes that are stable for dsRNA treated beetles will serve as an important guide for their selection in future RNAi studies, a valuable tool of reverse genetics, and importantly a developing management tool, though additional efforts to verify reference gene stability across the specific conditions used in future RNAi studies are required. Due to the requirement of a $\geq 16$ base pair match for gene silencing to occur ${ }^{24}$, with careful selection of the target gene sequences dsRNAs can be engineered to be highly specific to the target insect. Thus, utilizing RNAi for pest suppression could offer a means for managing for I. calligraphus while minimizing harmful effects on non-target organisms, one barrier to use of traditional insecticides to prevent and reduce outbreak populations. Further work establishing the practicality of potential 


\begin{tabular}{|c|c|c|c|c|}
\hline Gene name & Sequence $5^{\prime} 3^{\prime}$ & $\mathbf{R}^{2}$ & $\% \mathrm{E}$ & Accession number \\
\hline \multirow{2}{*}{ 18s rRNA-18S Ribosomal RNA } & CACCGGAAGGATTGACAGAT & \multirow{2}{*}{0.99} & \multirow{2}{*}{95.8} & \multirow{2}{*}{ KJ531060.1 } \\
\hline & GTGGAGCGATTTGTCTGGTT & & & \\
\hline \multirow{2}{*}{ 16s $r R N A-16 \mathrm{~S}$ Ribosomal RNA } & CAAACCTTTCATTCCAGCTTTC & \multirow{2}{*}{0.99} & \multirow{2}{*}{103.8} & \multirow{2}{*}{ AF397475.1 } \\
\hline & AAAATACTGCGGCCGTTAAA & & & \\
\hline \multirow{2}{*}{ 28s rRNA-28S Ribosomal RNA } & TCGACCTCTGGTGACTGTTG & \multirow{2}{*}{0.99} & \multirow{2}{*}{105.4} & \multirow{2}{*}{ KJ531116.1 } \\
\hline & ACTTTCAGGACCCGTCTTGA & & & \\
\hline \multirow{2}{*}{ efla-Elongation Factor-1 alpha } & TTGGAACCATCCACCAAGAT & \multirow{2}{*}{0.99} & \multirow{2}{*}{91.9} & \multirow{2}{*}{ KJ531172.1 } \\
\hline & GATGCTTTGGATGCCATTCT & & & \\
\hline \multirow{2}{*}{ cad-Carbamoyl-Phosphate Synthetase 2} & CGACATTTTGGGGTTGTAGG & \multirow{2}{*}{0.99} & \multirow{2}{*}{90.0} & \multirow{2}{*}{ KF862878.2 } \\
\hline & ATTGAAGTGAACGCCAGGTT & & & \\
\hline \multirow{2}{*}{ coi-Cytochrome Oxidase I } & CATGGGGCTCAAATTTCCT & \multirow{2}{*}{0.99} & \multirow{2}{*}{95.9} & \multirow{2}{*}{ AF113335.1 } \\
\hline & CACAGGAGTCATTCTTGCCA & & & \\
\hline
\end{tabular}

Table 2. Six candidate reference genes, with their $\mathrm{qPCR}$ primer sequence, $\mathrm{R}^{2}$ correlation coefficient, percent primer efficiency, and accession number.

methods of delivering dsRNA, such as root drenches, trunk injections, or transgenically expressed dsRNA, will be critical to deployment of this innovative technology, and will enhance our understanding of how it may be implemented in a forest ecosystem.

Climate change, with associated shifts in temperature and rainfall, have made forests more susceptible to large outbreaks in which stressed, and even healthy trees are killed. In these conditions, traditional management techniques like silvicultural control measures are not sufficient to promote healthy forests, and begin to lose their efficacy. These concerns, in addition to the threat that the beetle may pose in its expanding introduced ranges, mean that a new technique must be added to our existing integrated pest management strategies, for which RNAi could be invaluable. Moreover, I. calligraphus represents just one species in a genus comprised of multiple devastating forest pests, including the massively destructive Ips typographus. Outbreaks of I. typographus have caused unparalleled damage in European forests, killing millions of trees and even nearly eliminating its primary host, Norway spruce (Picea abies), in affected areas ${ }^{31}$. These outbreaks are devastating ecologically, representing the loss of key carbon sinks and wildlife habitat, as well as a loss of genetic diversity associated with old growth forests that will be vital to adaptation and survival of these forests in the face of rapidly changing environmental conditions $^{31}$. I. typographus has been intercepted repeatedly at North American ports ${ }^{32}$, and when coupled with its potential for expanding suitable ranges with climate change $e^{33,34}$, it becomes evident that forests across the globe are at great risk of damage by this beetle. As I. calligraphus outbreak populations respond to increasingly frequent disturbance events and invade naïve ranges, and other Ips species continue to devastate forests globally, the ability to apply modern molecular techniques in innovating new management approaches is critical.

\section{Materials and methods}

Gene selection. Candidate reference genes (Table 2) were selected because they are transcribed in all cells and have essential functions that are ubiquitously expressed across cell types. Sequences were obtained from previous entries to NCBI, and primers were designed using the online tool Primer3Plus ${ }^{35}$. Primer pairs with an amplicon length between $80-120 \mathrm{bp}$, a GC\% of $\sim 50 \%$, and a melt temperature of $60^{\circ} \mathrm{C}$, as well as with the lowest self and any scores, were selected. Primers were only selected if the linear regression coefficient $\left(R^{2}\right)$ was $>0.99$ and efficiency percentage was $90-110 \%$.

Insects. Experimental insects (Ips calligraphus calligraphus) were obtained by suspending I. calligraphus lures (Synergy Semiochemicals Corporation, Delta, BC) on a plantation located on Florida Forestry Service land in Newnans Lake State Forest in central Florida for a two-week period in January 2020. Infested trees were felled by Florida Forestry Service personnel in compliance with institutional, national, and international guidelines addressing collections of plant material, and in compliance with IUCN provisions. Stems were immediately transported to the University of Kentucky, Lexington, $\mathrm{KY}$, and stored at $4{ }^{\circ} \mathrm{C}$. Stems were sectioned and transferred to rearing bins $(55.6 \times 62.7 \times 81.3 \mathrm{~cm})$ as needed. Beetles used to evaluate stability of gene expression based on sex and developmental stage were processed immediately, otherwise newly emerged beetles were maintained under specified conditions for $72 \mathrm{~h}$ to assess the stability of potential reference genes ${ }^{18,19}$. Beetles were sexed using the presence or absence of the pars stridens and the number of protibial spurs ${ }^{36}$. To evaluate developmental stage, adults, pupae, and larvae were collected by debarking an infested log and preserving for RNA extraction immediately. To evaluate reference stability of gene expression based on host plant, beetles were starved for $24 \mathrm{~h}$, then fed white (P. strobi) or loblolly pine bark; beetles for each treatment fed on the same piece of bark, and feeding was confirmed by visual inspection of beetles within galleries and the presence of frass. Beetles were maintained at $20^{\circ} \mathrm{C}$ and $25^{\circ} \mathrm{C}$ to evaluate stability of gene expression based on temperature, and 16:8 L:D and total darkness to evaluate stability based on photoperiod. dsRNA treated beetles were individually fed $10 \mu \mathrm{g}$ of green fluorescent protein dsRNA, and then after their four-hour feeding period kept for $72 \mathrm{~h}$ before RNA preservation. Excluding the sex and developmental stage treatments, all beetles were maintained in each respective 


\begin{tabular}{|l|l|}
\hline Gene name & Sequence $\mathbf{5}^{\prime} \mathbf{3}$ \\
\hline \multirow{2}{*}{ s $\mathbf{y}^{\prime} \mathrm{F} P$ - green fluorescent protein } & TAATACGACTCACTATAGGGCGATGCCACCTACGGCAA \\
\cline { 2 - 2 } & TAATACGACTCACTATAGGGTGTCGCCCTCGAACTTCA \\
\hline
\end{tabular}

Table 3. Green fluorescent protein dsRNA forward and reverse primers, with T7 promoter sequence.

condition for $72 \mathrm{~h}$ before being crushed directly into TRIzol reagent (Life Technologies, Carlsbad, CA) to ensure maximum RNA yield.

Gene expression. Total RNA was extracted using TRIzol reagent, precipitated using isopropanol, and washed twice with 75\% ethanol before being resuspended in nuclease free water. Nanodrop spectrometry was used to ensure RNA integrity, followed by cDNA synthesis with 400 ng total RNA, using the SuperScript III Reverse Transcriptase protocol according to manufacturer's protocols. cDNA synthesis was followed by quantitative PCR on a fivefold dilution of CDNA, starting at a 1:25 dilution with each primer pair to calculate percent primer efficiency, to check for single melt curve to ensure no primer dimers, and to determine the ideal concentration to evaluate treatments (three technical replicates each). Quantitative PCR gene expression analysis was performed on cDNA of each individual beetle (diluted 1.6 E-3) $(n=5)$ from each treatment with the six primer pairs. Expression was determined for each candidate gene using the $\mathrm{Cq}$ (quantification cycle) value, the number of PCR cycles required to meet a detection threshold. All qPCR reactions were performed with the QuantStudio 3 Real Time PCR System (ThermoFisher Scientific, Waltham, MA) using PowerUp SYBR Green Master Mix (ThermoFisher Scientific, Waltham, MA). PCR reactions were performed (at $50{ }^{\circ} \mathrm{C}$ for $2 \mathrm{~min}, 95{ }^{\circ} \mathrm{C}$ for $2 \mathrm{~min}$, $\left(95{ }^{\circ} \mathrm{C} 1 \mathrm{~s}, 60{ }^{\circ} \mathrm{C} 30 \mathrm{~s}\right) \times 40$ ), followed by a melt curve analysis (at $60{ }^{\circ} \mathrm{C} 1 \mathrm{~min}, 95^{\circ} \mathrm{C} 15 \mathrm{~s}$ ), and each plate included a no template control for each primer pair.

Stability analysis. Using the mean Cq value for each beetle per primer pair, stability was analyzed using RefFinder, which combines GeNorm, NormFinder, BestKeeper, and the delta-cq method, and produces a final ranking of the potential reference genes based on the geometric mean of the four methods ${ }^{28}$.

dsRNA synthesis. Traditional PCR was performed using OneTaq 2X Master Mix with Standard Buffer (New England Biolabs, Ipswich, MA) from purified PCR template (Table 3) (at $94{ }^{\circ} \mathrm{C}$ for $30 \mathrm{~s},\left(94{ }^{\circ} \mathrm{C} 30 \mathrm{~s}, 60{ }^{\circ} \mathrm{C}\right.$ $\left.1 \mathrm{~min}, 68{ }^{\circ} \mathrm{C} 1 \mathrm{~min}\right) \times 30,68{ }^{\circ} \mathrm{C} 5 \mathrm{~min}, 4.0^{\circ} \mathrm{C} \infty$ ), and PCR products were purified using the QIAquick PCR purification kit (Qiagen, Germantown, MD). This purified PCR product was then used to synthesize dsRNA using the MEGAscript RNAi Kit (Invitrogen, Waltham, MD). The quality and quantity of dsRNA was tested using NanoDrop spectrometry and gel electrophoresis.

Administering dsRNA. To administer the dsRNA treatments, $10 \mu \mathrm{g}$ of dsRNA was suspended in a $0.5 \%$ sucrose solution containing $0.5 \%$ food dye in a $0.5 \mathrm{~mL}$ microcentrifuge tube, for a total of $4 \mu \mathrm{L}$ of solution. The anterior end of each individual beetle was immersed in the solution up to the pronotum, so as to not interfere with spiracles and oxygen uptake. A KimWipe (Kimtech, Neenah, WI) was placed into the tube to prevent beetles from backing out until the solution was completely consumed $(\sim 4 \mathrm{~h})^{20}$. After treatment exposure, beetles were placed in petri dishes $(60 \times 15 \mathrm{~mm})$ lined with moistened KimWipes, and oriented vertically in a cylindrical humidity chamber $(\sim 23 \times 21 \mathrm{~cm})$ for $72 \mathrm{~h}$ at $23^{\circ} \mathrm{C}$.

Received: 4 June 2021; Accepted: 18 November 2021

Published online: 07 December 2021

\section{References}

1. Hopping, G. R. The North American species in Group X of Ips De Geer (Coleoptera: Scolytidae). Can. Entomol. 97, 803-809. https://doi.org/10.4039/Ent97803-8 (1965).

2. Wood, D. L. \& Stark, R. W. The life history of Ips calligraphus (Coleoptera: Scolytidae) with notes on its biology in California. Can. Entomol. 100, 145-151. https://doi.org/10.4039/Ent100145-2 (1968).

3. Haack, R. A., Foltz, J. L. \& Wilkinson, R. C. Longevity and fecundity of Ips calligraphus (Coleoptera: Scolytidae) in relation to slash pine phloem thickness. Ann. Entomol. Soc. Am. 77, 657-662. https://doi.org/10.1093/aesa/77.6.657 (1984).

4. Miller, D. R. \& Rabaglia, R. J. Ethanol and (-)-a-Pinene: Attractant kairomones for bark and ambrosia beetles in the Southeastern US. J. Chem. Ecol. 35, 435-448. https://doi.org/10.1007/s10886-009-9613-9 (2009).

5. Garraway, E. The biology of Ips calligraphus and Ips grandicollis (Coleoptera: Scolytidae) in Jamaica. Can. Entomol. 118, 113-121. https://doi.org/10.4039/Ent118113-2 (1986).

6. Easterling, D. R. et al. Climate extremes: observations, modeling, and impacts. Science 289, 2068-2074. https://doi.org/10.1126/ science.289.5487.2068 (2000).

7. Li, W., Li, L., Fu, R., Deng, Y. \& Wang, H. Changes to the North Atlantic subtropical high and its role in the intensification of summer rainfall variability in the Southeastern United States. J. Clim. 24, 1499-1506. https://doi.org/10.1175/2010jcli3829.1 (2011).

8. Li, L., Li, W. \& Deng, Y. Summer rainfall variability over the Southeastern United States and its intensification in the 21 st century as assessed by CMIP5 models. J. Geophys. Res. Atmos. 118, 340-354. https://doi.org/10.1002/jgrd.50136 (2013).

9. Marini, L. et al. Climate drivers of bark beetle outbreak dynamics in Norway spruce forests. Ecography 40, 1426-1435. https://doi. org/10.1111/ecog.02769 (2017).

10. Clarke, S. R. \& Billings, R. Influence of pine bark beetles on the West Gulf Coastal Plain. Tex J Sci 52, 105-126 (2000).

11. Haack, R. A., Billings, R. F. \& Richter, A. M. Life history parameters of bark beetles (Coleoptera: Scolytidae) attacking West Indian pine in the Dominican Republic. Fla. Entomol. 72, 591-603. https://doi.org/10.2307/3495033 (1989). 
12. Morris, J. L. et al. Managing bark beetle impacts on ecosystems and society: priority questions to motivate future research. J. Appl. Ecol. 54, 750-760. https://doi.org/10.1111/1365-2664.12782 (2017).

13. Zamora, R. A. \& Lapis, E. B. Life history and phenology of Ips calligraphus Germar in Benguet province [Philippines]. Philippine Technology Journal 12, 43-60 (1987).

14. Li, Y., Johnson, A. J., Gao, L., Wu, C. \& Hulcr, J. Two new invasive Ips bark beetles (Coleoptera: Curculionidae) in mainland China and their potential distribution in Asia. Pest Manag. Sci. https://doi.org/10.1002/ps.6423 (2021).

15. Lantschner, M. V., Atkinson, T. H., Corley, J. C. \& Liebhold, A. M. Predicting North American Scolytinae invasions in the Southern Hemisphere. Ecol. Appl. 27, 66-77. https://doi.org/10.1002/eap.1451 (2017).

16. Fishilevich, E. et al. RNAi as a management tool for the western corn rootworm Diabrotica virgifera virgifera. Pest Manag, Sci. 72, 1652-1663. https://doi.org/10.1002/ps.4324 (2016).

17. Sun, Y. et al. Silencing an essential gene involved in infestation and digestion in grain aphid through plant-mediated RNA interference generates aphid-resistant wheat plants. Plant Biotechnol. J. 17, 852-854. https://doi.org/10.1111/pbi.13067 (2019).

18. Rodrigues, T. B., Duan, J. J., Palli, S. R. \& Rieske, L. K. Identification of highly effective target genes for RNAi-mediated control of emerald ash borer Agrilus planipennis. Sci. Rep. 8, 5020. https://doi.org/10.1038/s41598-018-23216-6 (2018).

19. Kyre, B. R., Rodrigues, T. B. \& Rieske, L. K. RNA interference and validation of reference genes for gene expression analyses using qPCR in southern pine beetle Dendroctonus frontalis. Sci. Rep. 9, 5640. https://doi.org/10.1038/s41598-019-42072-6 (2019).

20. Kyre, B. R., Bentz, B. J. \& Rieske, L. K. Susceptibility of mountain pine beetle (Dendroctonus ponderosae Hopkins) to gene silencing through RNAi provides potential as a novel management tool. For. Ecol. Manage. 473, 118322. https://doi.org/10.1016/j.foreco. $2020.118322(2020)$.

21. Pampolini, F. \& Rieske, L. K. Emerald ash borer specific gene silencing has no effect on non-target organisms. Front. Agron. https:// doi.org/10.3389/fagro.2020.608827 (2020).

22. Mussabekova, A., Daeffler, L. \& Imler, J. L. Innate and intrinsic antiviral immunity in Drosophila. Cell Mol Life Sci 74, $2039-2054$. https://doi.org/10.1007/s00018-017-2453-9 (2017).

23. Mamta, B. \& Rajam, M. V. RNAi technology: a new platform for crop pest control. Physiol. Mol. Biol. Plants 23, 487-501. https:// doi.org/10.1007/s12298-017-0443-x (2017).

24. Chen, J. et al. Off-target effects of RNAi correlate with the mismatch rate between dsRNA and non-target mRNA. RNA Biol. https:// doi.org/10.1080/15476286.2020.1868680 (2021).

25. Sen, G. L. \& Blau, H. M. A brief history of RNAi: the silence of the genes. FASEB J. 20, 1293-1299. https://doi.org/10.1096/fj.066014rev (2006).

26. Vandesompele, J. et al. Accurate normalization of real-time quantitative RT-PCR data by geometric averaging of multiple internal control genes. Geno. Biol. https://doi.org/10.1186/gb-2002-3-7-research0034 (2002).

27. Shakeel, M., Rodriguez, A., Tahir, U. A. \& Jin, F. Gene expression studies of reference genes for quantitative real-time PCR: an overview in insects. Biotech. Lett. 40, 227-236 (2018).

28. Xie, F., Xiao, P., Chen, D., Xu, L. \& Zhang, B. miRDeepFinder: a miRNA analysis tool for deep sequencing of plant small RNAs. Plant Mol. Biol. 80, 75-84. https://doi.org/10.1007/s11103-012-9885-2 (2012).

29. Heid, C. A., Stevens, J., Livak, K. J. \& Williams, P. M. Real time quantitative PCR. Genome Res. 6, 986-994 (1996).

30. Bustin, S. A., Benes, V., Nolan, T. \& Pfaffl, M. W. Quantitative real-time RT-PCR - a perspective. J. Mol. Endocrinol. 34, 597-601. https://doi.org/10.1677/jme.1.01755 (2005).

31. Nowakowska, J. A. et al. Health assessment and genetic structure of monumental Norway spruce trees during a bark beetle (Ips typographus L.) Outbreak in the Białowieża Forest District Poland. Forests 11, 647 (2020).

32. Liebhold, A. M., Brockerhoff, E. G. \& Kimberley, M. Depletion of heterogeneous source species pools predicts future invasion rates. J. Appl. Ecol. 54, 1968-1977. https://doi.org/10.1111/1365-2664.12895 (2017).

33. Bentz, B. J. et al. Ips typographus and Dendroctonus ponderosae models project thermal suitability for intra- and inter-continental establishment in a changing climate. Front. For. Glob. Change https://doi.org/10.3389/ffgc.2019.00001 (2019).

34. Jönsson, A. M., Harding, S., Bärring, L. \& Ravn, H. P. Impact of climate change on the population dynamics of Ips typographus in southern Sweden. Agric. For. Meteorol. 146, 70-81. https://doi.org/10.1016/j.agrformet.2007.05.006 (2007).

35. Untergasser, A. et al. Primer3-new capabilities and interfaces. Nucl. Acids Res. 40, el15-e115. https://doi.org/10.1093/nar/gks596 (2012).

36. Lanier, G. N. \& Cameron, E. A. Secondary sexual characters in the North American species of the genus Ips (Coleoptera: Scolytidae). Can. Entomol. 101, 862-870. https://doi.org/10.4039/Ent101862-8 (1969).

\section{Acknowledgements}

The authors thank Jeffrey Eickwort, Holly Foster, Hannah Hollowell, and J. David Wallace for assistance obtaining beetles, and Zachary Bragg, Bethany Kyre, and Flávia Pampolini for laboratory assistance. This work was supported by funds provided by USDA APHIS AP20PPQS\&T00C061, the University of Kentucky, and the Kentucky Agricultural Experiment Station under McIntire-Stennis 2351197000, and is published with the approval of the director.

\section{Author contributions}

M.C.W. and L.K.R. conceived the experiments; M.C.W. conducted the experiments; M.C.W. and L.K.R. analyzed the results; M.C.W. and L.K.R. prepared the manuscript. All authors approved the manuscript.

\section{Competing interests}

The authors declare no competing interests.

\section{Additional information}

Correspondence and requests for materials should be addressed to L.K.R.

Reprints and permissions information is available at www.nature.com/reprints.

Publisher's note Springer Nature remains neutral with regard to jurisdictional claims in published maps and institutional affiliations. 
(c) (i) Open Access This article is licensed under a Creative Commons Attribution 4.0 International cc) License, which permits use, sharing, adaptation, distribution and reproduction in any medium or format, as long as you give appropriate credit to the original author(s) and the source, provide a link to the Creative Commons licence, and indicate if changes were made. The images or other third party material in this article are included in the article's Creative Commons licence, unless indicated otherwise in a credit line to the material. If material is not included in the article's Creative Commons licence and your intended use is not permitted by statutory regulation or exceeds the permitted use, you will need to obtain permission directly from the copyright holder. To view a copy of this licence, visit http://creativecommons.org/licenses/by/4.0/.

(C) The Author(s) 2021 